\title{
RELATIONS BETWEEN BIG FIVE PERSONALITIES, MOTIVATION TO FAKE, AND APPLICANT FAKING BEHAVIOR
}

\author{
Aldo Prasmara ${ }^{1^{*}}$, Nikodemus Hans Setiadi Wijaya ${ }^{2}$ \\ ${ }^{1,2}$ Graduate Program, Master of Management, ${ }^{2}$ Department of Management, \\ YKPN School of Business (STIE YKPN), Yogyakarta, Indonesia \\ *Corresponding author; Email: aprasmara@gmail.com
}

\begin{abstract}
The action of faking is often done by applicants in the process of recruitment and selection of new employees with the purpose to impress an employer. The aim of this study is to integrate the big five personalities, faking motivation, and faking behavior. That is, the personality dimensions of applicants based may be the source of faking motivation, in turn, faking behavior. The data were gathered by questionnaires done toward 200 applicants. Data analysis was conducted using a Structural Equation Modelling (SEM) in the AMOS 22. Results showed that in the five major categories of personalities, there was a dimension that was not significantly related to motivation to fake, i.e., neuroticism, while openness and extraversion positively influenced motivation to fake. The other dimensions, conscientiousness and agreeableness, showed negative effects on motivation to fake. Finally, motivation to fake showed a positive effect on applicants' faking behavior.
\end{abstract}

Keywords: Faking, big five personality, motivation to fake, faking behavior.

\section{Introduction}

Basically, people need a job which is suitable to his needs. Job has an important meaning, that is, through the activity undertaken, employees can satisfy their needs for living. In short, a job is intended to get income. Therefore, to get a job, applicants should look for vacancies, which they can compete with other applicants. In most conditions, the number of applicants is fewer than the number of vacancies offered. Employee recruitment and selection processes are also tightened so that a person's chance of getting a job is getting harder.

In the context of the unemployment rate, particularly in Indonesia, there are still many people who need jobs. This is proven by the unemployment rate in February 2016 reached 7.02 million people (Wibowo, 2016). Looking at the unemployment rate, it is not surprising that people are competing to find jobs. In this intense competition, an applicant will try to give a good impression to any targeted company, so that he may be judged positively by recruiters.

This study focuses on the impact of big five personalities on faking motivation. The big five personality consists of five different dimensions. If they are presented together, they will give a view of how a person is responding to a situation or to another person. These dimensions are openness to experience, conscientiousness, extraversion, agreeableness, and neuroticism (Landy \& Conte, 2004). Ziegler, Mac Cann, and Roberts (2011) argued that 30\% of job applicants were involved in faking behavior and managed to impress their recruiters during tests. However, not all faking types are similar, some people do faking to make them look more memorable, while some others to manipulate (Peterson, Griffith, Isaacson, O'Connell, \& Mangos, 2011).

A previous research by Levashina \& Campion (2006) showed that faking is a function of capacity, willingness, and opportunity to fake. Levashina and Campion (2006) also mentioned that some other structures or components may increase the faking. However, the prior study has not yet determined any other components that may improve the action of faking. Jerneić and Grabovac (2015) found that faking behavior is influenced by faking motivation (see also McFarland \& Ryan, 2006). Peterson, Griffith, and Converse (2009) only included conscientiousness as a dependent variable. Meanwhile, Yu (2008) used the theory of planned behavior to test faking behaviors and developed by adding basic individual differences, i.e., conscientiousness. In her research, conscientiousness has a negative effect on faking (Yu, 2008). Therefore, this paper introduces a process model based on existing literature as well as presents some new research to further elucidate the actions of faking.

\section{Hypotheses Development}

McShane and Von Glinow (2000) revealed that big five personality dimensions consist of consci- 
entiousness, emotional stability, openness to experience, agreeableness, and extraversion. John (1990) abbreviated the five personality dimensions as OCEAN, which is openness $(\mathrm{O})$, conscientiousness $(\mathrm{C})$, extraversion $(\mathrm{E})$, agreeableness $(\mathrm{A})$, and neuroticcism $(\mathrm{N})$. The dimension of openness measures the value of the individual based on his interest in new things and the desire to know and learn something new. Conscientiousness describes the regularity, discipline and desire to achieve an achievement. Individuals with a high conscientiousness tend to be more careful in performing an action or in making decisions. Extraversion relates to the comfort levels of a person in interacting with others. Individuals with a high agreeableness tend to be easy to cooperate, to avoid conflict, to understand the diversity and not always to impose the will, and dislike to argue. Neuroticism is the dimension of personality that assesses a person's ability to withstand stress. In addition, neuroticism is often described as the emotional instability and the frequency of individuals experiencing negative emotional situations.

Motivation can be interpreted as a stimulus that can move and keep someone moving, an action will occur because there is encouragement or motivation to drive so. In relation to faking, the most common and acceptable definition of faking is the distortion, twisting, or counterfeiting of deliberate responses in order to create a particular impression or to give the best answer (Comrey \& Backer, 1975). To do the faking, the individual must simply be willing and able to do so. The need for a job and the confidence of job applicants about faking in order to get a job is a strong motivator to perform the action of faking (Kiefer \& Benit, 2016). Applicant faking behavior (AFB) is the behavior of job applicants in a recruitment selection procedure that may include any response to a personality test that is inconsistent with true applicant's self-image (Kiefer \& Benit, 2016). A deeper definition of AFB is an individual's conscious effort to present misleading and deceptive information about personality, interests, experiences, past behavior, and attitudes that aim to influence others (Kuncel \& Borneman, 2007).

Individuals with a strong openness dimension will allow to have an influence on motivation to fake. This is possible with an attitude of openness to a new thing. Someone will be motivated to do faking by pretending to be friendly and open during the interview process, or by open-minded and always agree with any interviewer questions. In accordance to the logic, thus:

$H_{l}$ : There is a positive influence of openness on motivation to fake.
Individuals with high conscientiousness scores will be more honest in the recruitment process. They feel uncomfortable in doing something that is not appropriate, therefore high conscientiousness individuals may be less likely motivated to fake than individuals with low conscientiousness individuals (McFarland \& Ryan, 2000). Based on the logic, it can be suggested:

$\mathrm{H}_{2}$ : There is a negative influence of conscientiousness on motivation to fake.

Kashy and DePaulo (1996) found that friendly people (defined as extroverts) tend to lie in daily conversation. However, an extrovert person is judged to be more trustworthy even if they are being honest or lying. Moreover, Kristof-Brown, Barrick and Franke (2002) found that people with extravertion personalities engage in self-promotion during interviews which may influence the perception of interviewers in the process of evaluation. Based on this reasoning, it can be suggested:

$H_{3}$ : There is a positive effect of extraversion on motivation to fake.

A person with a high agreeableness score tends to adhere to social norms and does not do faking (Paulhus \& John, 1998). McLeod and Genereux (2008) found that the measure of kindness is similar to agreeableness and has a negative influence associated with faking for the sake of personal interest. A person with this nature will tend to avoid conflicts during the job interview process, which may include the avoidance of faking acts. Therefore:

$H_{4}$ : There is a negative influence of agreeableness on motivation to fake.

Turcu (2011) pointed out that low emotional stability is likely to be related to motivation to fake. In the process of applying for a job, a person with a neuroticism personality will be likely motivated to do faking to cover his emotions and nervousness. They will pretend to be confident in behaving and talking, however actually they are depressed. Hence:

$H_{5}$ : There is a positive influence of neuroticism on motivation to fake.

The desire to perform faking has a direct effect on faking behavior (McFarland \& Ryan, 2000). The direct determinant of any behavior is the motivation to perform or not to do (Ajzen, 1992), as well as applicant faking behavior that is influenced by motivation to fake. Consistent with that statement, motivation can lead to behavior. Therefore, if the motivation is high, the possibility to perform faking also high, and if the motivation is low, the possibility to do faking is also low. 
$H_{6}$ : There is a positive influence of motivation to fake on applicant faking behavior.

\section{Research Method}

Data were gathered from job applicants in the job fair held at Hartono Mall on 6-7 December 2016. Two hundred applicants were randomly chosen during the time job. They were requested to fill out the paper-based questionnaire. All measures were used Likert scale anchored from 1 (totally disagree) to 7 (totally agree).

\section{Measurement}

Measuring the big five personality dimensions is using the scale from BFI (John, 1990), adapted by Ramdhani (2012) to Bahasa Indonesia, which consists of a six-item scale for openness with a sample item "I am imaginative." The Cronbach's $\alpha$ for this scale is 0.852 . A five-item scale for conscientiousness with a sample item is "I am persistent to perform tasks until finish." The Cronbach's $\alpha$ for this scale is 0.867 . A five-item scale for extraversion with a sample item is "I am an easy to get along going and nice." The Cronbach's $\alpha$ for this scale is 0.789. A five-item scale for agreeableness with a sample item is "I am a pardoning one." The Cronbach's $\alpha$ for this scale was 0.771 . A four-item scale for neuroticism with a sample item is "I am a worried person often." The Cronbach's $\alpha$ for this scale is 0.906 . Response options ranged from 1 (totally disagree) to 7 (totally agree).

In measuring motivation to fake, Barrick, Parks, and Mount (2005) said that self-monitoring can explain faking behavior, so a five-item self-monitoring scale from (Goldberg, 1999) is used to measure motivation to fake. A sample item is "I am a man who can play to impress people." The Cronbach's $\alpha$ for this scale is 0.728 . Response options ranged from 1 (totally disagree) to 7 (totally agree).

In measuring applicant faking behavior, a fourteen-item based on Balanced Inventory of Desirable Responding (BIDR) by McFarland and Ryan (2006) is used to measure faking behavior. Six items were dropped (see details in the next section). A sample item is "Never regretted the decision made." The Cronbach's $\alpha$ for this scale is 0.740 . Response options ranged from 1 (totally disagree) to 7 (totally agree).

Control variables include gender (female $=1$, male $=0$ ), age divided into three category which (under 20 =1,20-30 years old $=2$, over $30=3$ ), education (high school $=1$, diploma $3=2$, undergraduate $=3$, postgraduate $=4$ ), employee status (employed $=1$, unemployed $=2$ ).

\section{Result and Discussion}

\section{Validity and Reliability}

Validity of measures is assessed based on the criteria of item loading factor at least 0.4 according to Hair, Anderson, Babin, and Black (2010). It can be seen that on the applicant faking behavior variable, there are 6 invalid items consisting of afb1 item (loading $=0.136$ ), afb3 (loading $=0.147$ ), afb5 (loading $=0.139$ ), afb8 (loading $=0.312$ ), afb10 (loading $=0.265$ ), and afb11 (loading $=0.261$ ) due to their loading factor smaller than 0.4 , so they are not used in hypothesis testing as shown on Table 1.

Table 1

Validity Test Results

\begin{tabular}{llcc}
\hline \multicolumn{1}{c}{ Variable } & Item Code & Valid Item & $\begin{array}{c}\text { Invalid } \\
\text { Item }\end{array}$ \\
\hline $\begin{array}{l}\text { Openness } \\
\text { Conscientious- } \\
\text { ness }\end{array}$ & ope1 to ope6 & All Valid & - \\
Extraversion & ext1 to ext5 & All Valid & - \\
Agreeableness & agr1 to agr5 & All Valid & - \\
Neuroticism & neu1 to neu4 & All Valid & - \\
$\begin{array}{l}\text { Motivation to } \\
\text { Fake }\end{array}$ & smo1 to smo5 & All Valid & - \\
Applicant & afb1 to afb5 & afb2, afb4, & afb1, afb3, \\
Faking Behavior & & afb6, afb7, & afb5, afb8, \\
& & afb9, afb12, & afb10, \\
& & afb13, afb14 & afb11 \\
\hline
\end{tabular}

Reliability of the measures is checked based on the Cronbach's alpha value ( $\geq 0.7)$. In Table 2 , it can be seen that the Cronbach's Alpha value for each variable exceeds the threshold value of 0.7. The greater the value of Cronbach's alpha the better the research instrument. This shows that the remaining items can be used for further analysis.

Table 2

Reliability Test Results

\begin{tabular}{lcc}
\hline \multicolumn{1}{c}{ Variable } & $\begin{array}{c}\text { Cronbach's } \\
\text { Alpha }\end{array}$ & Category \\
\hline Openness & 0.852 & Very reliable \\
Conscientiousness & 0.867 & Very reliable \\
Extraversion & 0.789 & Reliable \\
Agreeableness & 0.771 & Reliable \\
Neuroticism & 0.906 & Very reliable \\
Motivation to fake & 0.728 & Reliable \\
Applicant Faking Behavior & 0.740 & Reliable \\
\hline
\end{tabular}


The mean of standard deviations, reliabilities, and correlations among the research variables are presented in Table 3. As shown, motivation to fake is correlated with openness to experience $(r=0.209, p<$ $0.01)$, extraversion $(r=0.350 p<0.01)$, and neuroticism $(r=-0.159, p<0.05)$. Applicant faking behavior are also correlated with education $(r=0.202, p<$ $0.01)$, openness to experience $(r=0.317, p<0.01)$, extraversion $(r=0.152, p<0.05)$, and neuroticism $(r$ $=-0.182, p<0.05)$.

\section{Hypotheses Testing}

Table 4 shows the result of the hypotheses testing. The first hypothesis is accepted. Openness to experience can affect a person's impulse in doing faking action; this is triggered by the personality which is easy to accept a new thing, including motivation to fake. Thus when someone with an openness to experience personality gets information about faking in the job applying process or even during a job interview, he tends to be motivated to perform such faking.

The second hypothesis was accepted. This indicates that the higher score of conscientiousness, the lower motivation to fake. This finding is consistent with the assertion that a person with low conscientiousness score has a better chance of faking than a high conscientiousness score (McFarland \& Ryan, 2000). Thus, when people have this conscientiousness personality, they will be more honest in the process of applying for jobs, because they feel uncomfortable doing actions that are considered to wrong (faking).

The third hypothesis is accepted. This is triggered by the personality of someone who are accustomed to socialization, so it is highly possible to do faking. The higher the extraversion score, the higher the motivation to fake. These findings are consistent with Levashina and Campion (2006) that extraversion can lead to faking action.

The fourth hypothesis is accepted. It is proven that a person who has an agreeableness personality tends to be unmotivated to perform faking actions; this is because they are more likely to adhere to social norms and do not do faking (Paulhus \& John, 1998). Salgado (2002) states in his research on big five factors and deviant behavior that the higher score of agreeableness the lower the impulse to take action faking.

Table 4

Summary of Hypotheses Testing Results

\begin{tabular}{|c|c|c|c|}
\hline Hypothesis & Estimate & $P$ & Result \\
\hline $\begin{array}{ll}H_{I} & \text { There is a positive } \\
\text { influence of openness } \\
\text { on motivation to fake. }\end{array}$ & 0.229 & $* * *$ & Supported \\
\hline $\begin{array}{l}\mathrm{H}_{2} \text { There is a negative } \\
\text { influence of } \\
\text { conscientiousness on } \\
\text { motivation to fake. }\end{array}$ & -0.267 & 0.025 & Supported \\
\hline $\begin{array}{l}H_{3} \text { There is a positive } \\
\text { effect of extraversion } \\
\text { on motivation to fake. }\end{array}$ & 0.277 & 0.004 & Supported \\
\hline $\begin{array}{l}H_{4} \text { There is a negative } \\
\text { influence of } \\
\text { agreeableness on } \\
\text { motivation } \\
\text { to fake. }\end{array}$ & -0.210 & 0.050 & Supported \\
\hline $\begin{array}{l}H_{5} \text { There is a positive } \\
\text { influence of } \\
\text { neuroticism on } \\
\text { motivation to fake. }\end{array}$ & -0.024 & 0.610 & Unsupported \\
\hline $\begin{array}{l}H_{6} \text { There is a positive } \\
\text { influence of } \\
\text { motivation to fake on } \\
\text { applicant faking } \\
\text { behavior. }\end{array}$ & 0.258 & 0.032 & Supported \\
\hline
\end{tabular}

Table 3

Descriptive Statistics

\begin{tabular}{ccccccccccccc}
\hline Variable Mean & SD & $\mathbf{1}$ & $\mathbf{2}$ & $\mathbf{3}$ & $\mathbf{4}$ & $\mathbf{5}$ & $\mathbf{6}$ & $\mathbf{7}$ & $\mathbf{8}$ & $\mathbf{9}$ & 10 \\
\hline JK & 1.52 & 0.57 & & & & & & & & & & \\
Age & 2.01 & 0.31 & 0.00 & & & & & & & & & \\
PD & 2.79 & 0.66 & 0.00 & $0.449 *$ & & & & & & & & \\
SB & 1.61 & 0.49 & 0.05 & -0.05 & 0.06 & & & & & & & \\
OPE & 5.05 & 1.07 & $0.191^{*}$ & -0.06 & -0.07 & 0.03 & & & & & & \\
CON & 5.24 & 1.06 & 0.02 & 0.11 & 0.06 & 0.04 & $0.301^{* *}$ & & & & & \\
EXT & 5.10 & 1.02 & 0.00 & -0.06 & -0.07 & 0.07 & $0.460^{* *}$ & $0.244^{* *}$ & & & & \\
AGR & 5.38 & 0.91 & 0.00 & -0.03 & 0.09 & $0.227^{* *}$ & $0.162^{* *}$ & $0.245^{* *}$ & $0.197^{*}$ & & & \\
NEU & 3.88 & 1.53 & $-.153^{*}$ & -0.05 & 0.12 & $0.264^{* *}$ & $-0.206^{* *}$ & -0.02 & $-0.309^{* *}$ & $.155^{*}$ & & \\
MTF & 4.58 & 0.99 & -0.04 & 0.04 & 0.05 & -0.08 & $0.209^{* *}$ & -0.09 & $0.350^{* *}$ & -0.09 & $-.159^{*}$ & \\
AFB & 4.73 & 0.96 & 0.04 & 0.03 & $0.202^{* *}$ & 0.03 & $0.317^{* *}$ & 0.08 & $0.152^{*}$ & 0.07 & $-0.182^{*}$ & 0.12 \\
\hline
\end{tabular}


The fifth hypothesis is rejected. This may be due to job applicants who have high levels of neuroticism feel that they have no chance of faking when they are feeling anxious or nervous during the job selection process. This condition is not in-line with the statement of McFarland and Ryan (2000) that someone with high neuroticism scores is someone who tends to perform faking action.

The sixth hypothesis is also accepted. Motivation to fake is the trigger to perform the action of faking which can affect a person in doing faking or an applicant faking the behavior. The results of this study are similar to those of Jerneić and Grabovac (2015) that faking motivation has a significant positive effect on faking behavior (Levashina \& Campion, 2006).

\section{Conclusions and Implications}

In this study, most hypotheses are proved acceptable, except one of big five personality variables of neuroticism which is proven to have no effect on motivation to fake. The reason is that job applicants who have a high neuroticism tend not to dare to do faking action when they were in a state of nervousness at the time of the job selection process.

The conclusion of this study is that faking behavior in the job applicant process can be caused by the personality of the applicants themselves, but each dimension of the big five personality has a certain opinion in assessing the action faking. Some applicants with high openness score assume that faking is an action that can be done, while some other applicants with high conscientiousness scores assume that faking is an action that is not in accordance with the rules or norms so it is worth to be avoided. Similar to the openness, some job applicants with high extraversion scores have the opinion that faking is a commonly used by job applicants, whereas high agreeableness applicants assume that faking as an action that can trigger conflicts so that job applicants tend to avoid faking.

\section{References}

Ajzen, I. (1992). Persuasive communication theory in social psychology: A historical perspective. In M. J. Manfredo (Ed.), Influencing human behavior: Theory and applications in recreation, tourism, and natural resource management (pp. 1-27). Champaign, IL: Sagamore Publishing.

Barrick, M. R., Parks, L., \& Mount, M. K. (2005). Self-monitoring as a moderator of the relationships between personality traits and performance. Personnel Psychology, 58(3), 745-767.
Comrey, A. L. \& Backer, T. E. (1975). Detection of faking on the Comrey personality scales. Multivariate behavioral research, 10(3), 311-319.

Goldberg, L. R. (1999). International personality item pool: A scientific collaboratory for the development of advanced measures of personality and other individual differences. Available at ipip. ori.org/ipip/. Accessed February, 1, 2017.

Hair, J. F., Anderson, R. E., Babin, B. J., \& Black, W. C. (2010). Multivariate data analysis: A global perspective, 7. Pearson Upper Saddle River, NJ.

Jerneić, Ž. \& Grabovac, M. T. (2015). Applicant faking behavior on personality questionnaires: An empirical model of motivational faking determinants. Paper presented at the 14th European Congress of Psychology.

John, O. (1990). The "big five" factor taxonomy: Dimensions of personality the natural language and questionnaires. In. L.A. Pervin (Ed.), Handbook of personality: Theory and research, 66100. New York: Guilford Press.

Kashy, D. A. \& DePaulo, B. M. (1996). Who lies? Journal of Personality and Social Psychology, 70(5), 1037-1051.

Kiefer, C. \& Benit, N. (2016). What is Applicant faking behavior? A review on the current state of theory and modeling techniques. Journal of European Psychology Students, 7(1), 9-19.

Kristof-Brown, A., Barrick, M. R., \& Franke, M. (2002). Applicant impression management: Dispositional influences and consequences for recruiter perceptions of fit and similarity. Journal of Management, 28(1), 27-46.

Kuncel, N. R. \& Borneman, M. J. (2007). Toward a new method of detecting deliberately faked personality tests: The use of idiosyncratic item responses. International Journal of Selection and Assessment, 15(2), 220-231.

Landy, F. J. \& Conte, J. M. (2004). Work in the 21st century: An introduction to industrial and organizational psychology. Boston: McGraw-Hill.

Levashina, J. \& Campion, M. A. (2006). A model of faking likelihood in the employment interview. International Journal of Selection and Assessment, 14(4), 299-316.

McFarland, L. A. \& Ryan, A. M. (2000). Variance in faking across non cognitive measures. Journal of Applied Psychology, 85(5), 812-821.

- (2006). Toward an integrated model of applicant faking behavior. Journal of Applied Social Psychology, 36(4), 979-1016.

McLeod, B. A. \& Genereux, R. L. (2008). Predicting the acceptability and likelihood of lying: The interaction of personality with type of lie. Personality and Individual Differences, 45(7), 591596. 
McShane, S. \& Von Glinow, M. (2000). Organizational culture. New York: SL McShane.

Paulhus, D. L. \& John, O. P. (1998). Egoistic and moralistic biases in self-perception: The interplay of self-deceptive styles with basic traits and motives. Journal of personality, 66(6), 1025-1060.

Peterson, M. H., Griffith, R. L., \& Converse, P. D. (2009). Examining the role of applicant faking in hiring decisions: Percentage of fakers hired and hiring discrepancies in single and multiple predictor selection. Journal of Business and Psychology, 24(4), 373-386.

Peterson, M. H., Griffith, R. L., Isaacson, J. A., O'Connell, M. S., \& Mangos, P. M. (2011). Applicant faking, social desirability, and the prediction of counterproductive work behaviors. Human Performance, 24(3), 270-290.

Ramdhani, N. (2012). Adaptasi Bahasa dan budaya dari skala kepribadian big five. Jurnal Psikologi, 39(2), 189-205.
Salgado, J. F. (2002). The big five personality dimensions and counterproductive behaviors. International Journal of Selection and Assessment, 10 (12), 117-125.

Turcu, R. (2011). The effects of warnings on applicant faking behavior. California State University, Sacramento.

Wibowo, K. S. (2016). BPS: Pengangguran terbuka di Indonesia capai 7,02 juta orang. Retrieved February 01, 2017, from https://nasional.tempo. co/read/768481/bps-pengangguran-terbuka-diindonesia-capai-702-juta-orang\#rgK3vQJOizTTo 3J9.99.

Yu, J. (2008). A process model of applicant faking on overt integrity tests. Unpublished doctoral dissertation, Texas A\&M University.

Ziegler, M., MacCann, C. \& Roberts, R. (2011). New perspectives on faking in personality assessment. Oxford: University Press. 